\title{
Dose-response model of murine typhus (Rickettsia typhi): time post inoculation and host age dependency analysis
}

\author{
Sushil B Tamrakar*, Yin Huang, Sondra S Teske and Charles N Haas
}

\begin{abstract}
Background: Rickettsia typhi (R. mooseri) is the causative agent of murine typhus. It is one of the most widely distributed flea-borne diseases with a relatively mild febrile initial illness with six to 14 days of incubation period. The bacterium is gram negative and an obligate intracellular pathogen. The disease is transmitted to humans and vertebrate host through fleabites or via contact with infected feces. This paper develops dose-response models of different routes of exposure for typhus in rodents.
\end{abstract}

Methods: Data from published articles were analyzed using parametric dose-response relationship models. Doseresponse relationships were fit to data using the method of maximum likelihood estimation (MLE).

Results: Dose-response models quantifying the effects of different ages of rats and time post inoculation in BALB/C mice were analyzed in the study. Both the adult rats (inoculated intradermally) and newborn rats (inoculated subcutaneously) were best fit by exponential models and both distributions could be described by a single doseresponse relationship. The BALB/C mice inoculated subcutaneously were best fit by Beta-Poisson models. The time post inoculation analysis showed that there was a definite time and response relationship existed in this case.

Conclusions: Intradermally or subcutaneously inoculated rats (adult and newborn) models suggest that less than 1 plaque-forming unit (PFU) (1.33 to 0.38 in 95\% confidence limits) of the pathogen is enough to seroconvert 50\% of the exposed population on average. For the BALB/C mouse time post inoculation model, an average dose of 0.28 plaque-forming units (PFU) (0.75 to 0.11 in 95\% confidence limits) will seroconvert 50\% of the exposed mice.

\section{Background}

Murine typhus, also known as endemic typhus, is one of the most widely distributed flea borne diseases. The causative agent of murine typhus is Rickettsia typhi, previously known as $R$. mooseri. It is a relatively mild febrile illness with 6 to 14 days of incubation period [1-3]. It is considered less pathogenic than $R$. rickettsii and $R$. prowazekii (in terms of mortality rate), but $R$. typhi is virulent enough to cause severe infection in the elderly population [3]. The major reservoir of the pathogens is the rat (Rattus rattus and $R$. norvegicus) with the rat flea (Xenopsylla cheopis) as the main vector. Fleas are infected by transovarian transmission or acquire the contagion while feeding on an infected animal [4]. $R$.

\footnotetext{
* Correspondence: sbt26@glink.drexel.edu

Department of Civil, Architectural and Environmental Engineering, Drexel University, Philadelphia, PA 10104, USA
}

typhi is transmitted to the human body or vertebrate host by infected fleabites, or contamination of the broken skin, respiratory tract or conjunctivae of the host with infected feces or tissues during and after flea feeding $[2,3]$.

The flea once acquiring the infection remains infective for life. Interestingly, neither flea nor rat is harmed by the pathogens [2]. Although humans are infected mainly via rat fleas, murine typhus exists endemically in many places where rat and rat fleas are absent [3]. In the United States, the reported cases of murine typhus are focused in south and central Texas, Los Angeles and Orange County, California, where rats and rat fleas are rarely documented. The cat flea/opossum cycle may be one of the possibilities responsible for the disease[5].

The clinical symptoms of infection with $R$. typhi in humans are fever, headache, and myalgia. The fever lasts about 12 days in adults with temperature ranges 
between 102-104F [6]. In severe cases the pathogen can cause meningoencephalitis, interstitial pneumonia and disseminated vascular lesions [7].

Many researchers have reported the response of animals to different doses of Rickettsia typhi in order to develop effective therapy and to study the pathology of infected animals. The purpose of this study is to develop dose-response models and to compare the responses in term of age, route of infection and time post inoculation.

\section{Methods}

Since there have been no previously reported doseresponse relations, the aim of this study was to extract usable data from the literature and develop doseresponse curves. Criteria for data used in our analysis are described as:

- Route of exposure is explicitly stated (such as inhalation, subcutaneous, intradermal, intravenous etc.)

- Methods for dose estimation are described clearly

- The number of subjects for each dose group is stated explicitly

- The number of positive responses for each exposure route is explicitly stated

- The criteria used to define a positive endpoint are stated

- Pathogen is described in detail (source, strain)

- The mode of preparation of pathogenic organisms is described

Aringo-Jaramillo et al. (1984) carried out an experiment with $R$. typhi infection in adult and newborn laboratory rats. Nine different doses of $R$. typhi were transdermally and subcutaneously inoculated with seroconversion and death as the responses defined as endpoints [8]. Animals with an indirect fluorescent antibody titer of greater than or equal to 1:40 were considered to be seroconverted $[9,10]$. However, no animals died.

Crist et al. (1984) experimented with $R$. typhi infection in normal and immune mice. Female BALB/c mice were subcutaneously inoculated with various doses of $R$. typhi and seroconversions on different days (after inoculation) were observed [10].

Aringo-Jaramillo et al. (1988) conducted experimental inoculation of $R$. typhi in young rats of different age groups. Five different doses were inoculated orally in 3day, 7 day and 30 day old rats and seroconversion was recorded as the endpoint of response [9].

\section{Analysis Method}

\section{Dose-response analysis}

Dose response relationships were fit to data using the method of maximum likelihood estimation (MLE) as described in Haas et al. (1999). All the data sets are shown in Table 1.
The statistical programming language, "R" http://www. r-project.org was used for this computation. Two dose response models (exponential and Beta-Poisson) were used [11]. Exponential and Beta-Poisson MLE estimates were made using the BFGS algorithm. Confidence intervals to the best-fit models were determined via bootstrapping with 10,000 bootstrap iterations.

The exponential dose-response model is given in equation (1)

$$
P(d)=1-e^{-k d}
$$

where $P(d)$ is the probability of response at dose $d$ and $k$ is the probability that a single organism can survive and initiate infection.

The Beta-Poisson model is given by equation (2)

$$
P(d)=1-\left[1+\left(\frac{d}{N_{50}}\right) \cdot\left(2^{1 / \alpha}-1\right)\right]^{-\alpha}
$$

where $\mathrm{N}_{50}$ is the median infective dose and $\alpha$ is the slope parameter for the Beta-Poisson model. The equation (2) is derived from the exact Beta-Poisson equation with certain assumptions $[11,12]$.

Goodness of fit for all models was determined by comparing the value of the optimized deviance to the critical $\chi^{2}$ value at degrees of freedom equal to the number of doses minus the number of fitted parameters at a 95\% confidence level. Assessment of the statistical significance of improvement of fit that a two parameter model would provide over a single parameter model was made by comparing the reduction in minimized deviance with the critical $\chi^{2}$ value at 1 degree of freedom. Confidence intervals for the best-fit model were estimated via bootstrapping [11].

Pooling analysis was performed for the different animals and bacterial species to ascertain whether the data set had the same underlying distributions. A likelihood ratio test was used to determine if data could be pooled.

\section{Time post inoculation analysis}

In the experiment conducted by Crist and co-investigators with BALB/c mice inoculated subcutaneously with R. typhi, the responses were also recorded at different post inoculation times [10]. Huang and Haas (2009) developed dose-response models incorporating time post inoculation as an additional parameter [13]. In the exponential model, the $k$ parameter is the probability that a single organism can survive and proliferate in order to initiate a response. It is well known that this is a time-dependent process, and phenomenological responses of animals to bacteria vary not only with the initial dose of microorganisms, but also with the time 
Table 1 Data Used

\begin{tabular}{|c|c|c|c|c|c|c|c|}
\hline $\begin{array}{l}\text { Pathogen/ } \\
\text { strain }\end{array}$ & $\begin{array}{l}\text { Study/ } \\
\text { Reference }\end{array}$ & $\begin{array}{c}\text { Mode of } \\
\text { inoculation }\end{array}$ & $\begin{array}{c}\text { Test animal/Response } \\
\text { Organism/Reponses end } \\
\text { point }\end{array}$ & Dose & $\begin{array}{l}\text { Number of Test } \\
\text { Animals }\end{array}$ & $\begin{array}{l}\text { Positive } \\
\text { Responses }\end{array}$ & $\begin{array}{l}\text { Negative } \\
\text { Responses }\end{array}$ \\
\hline \multirow[t]{7}{*}{$\begin{array}{c}\text { R. typhi } \\
\text { (Wilmington) }\end{array}$} & [10] & S.C. & $\begin{array}{c}\text { BALB/c mice } \\
\text { (sero-conversion on day 9) }\end{array}$ & $0.01(\mathrm{PFU})$ & 10 & 0 & 10 \\
\hline & & & & 0.1 & 10 & 0 & 10 \\
\hline & & & & 1 & 10 & 0 & 10 \\
\hline & & & & 10 & 10 & 0 & 10 \\
\hline & & & & 100 & 10 & 0 & 10 \\
\hline & & & & 1000 & 10 & 0 & 10 \\
\hline & & & & 10000 & 10 & 10 & 0 \\
\hline \multirow{7}{*}{$\begin{array}{l}\text { R. typhi } \\
\text { (Wilmington) }\end{array}$} & [10] & s.c. & BALB/c mice & $0.01(\mathrm{PFU})$ & 10 & 0 & 10 \\
\hline & & & & 0.1 & 10 & 0 & 10 \\
\hline & & & & 1 & 10 & 0 & 10 \\
\hline & & & & 10 & 10 & 0 & 10 \\
\hline & & & & 100 & 10 & 7 & 3 \\
\hline & & & & 1000 & 10 & 8 & 2 \\
\hline & & & & 10000 & 10 & 10 & 0 \\
\hline \multirow{7}{*}{$\begin{array}{c}\text { R. typhi } \\
\text { (Wilmington) }\end{array}$} & [10] & S.C. & BALB/c mice & $0.01(\mathrm{PFU})$ & 10 & 0 & 10 \\
\hline & & & & 0.1 & 10 & 0 & 10 \\
\hline & & & & 1 & 10 & 1 & 9 \\
\hline & & & & 10 & 10 & 5 & 5 \\
\hline & & & & 100 & 10 & 9 & 1 \\
\hline & & & & 1000 & 10 & 9 & 1 \\
\hline & & & & 10000 & 10 & 10 & 0 \\
\hline \multirow{7}{*}{$\begin{array}{l}\text { R. typhi } \\
\text { (Wilmington) }\end{array}$} & [10] & s.c. & BALB/c mice & 0.01 (PFU) & 10 & 0 & 10 \\
\hline & & & & 0.1 & 10 & 0 & 10 \\
\hline & & & & 1 & 10 & 5 & 5 \\
\hline & & & & 10 & 10 & 8 & 2 \\
\hline & & & & 100 & 10 & 9 & 1 \\
\hline & & & & 1000 & 10 & 10 & 0 \\
\hline & & & & 10000 & 10 & 10 & 0 \\
\hline \multirow{7}{*}{$\begin{array}{c}\text { R. typhi } \\
\text { (Wilmington) }\end{array}$} & [10] & s.c. & BALB/c mice & $0.01(\mathrm{PFU})$ & 10 & 0 & 10 \\
\hline & & & & 0.1 & 10 & 3 & 7 \\
\hline & & & & 1 & 10 & 8 & 2 \\
\hline & & & & 10 & 10 & 9 & 1 \\
\hline & & & & 100 & 10 & 10 & 0 \\
\hline & & & & 1000 & 10 & 10 & 0 \\
\hline & & & & 10000 & 10 & 10 & 0 \\
\hline \multirow[t]{3}{*}{$\begin{array}{l}\text { R. typhi } \\
\text { (Ethiopian) }\end{array}$} & [8] & i.d. & $\begin{array}{c}\text { Adult rat } \\
\text { (sero-conversion) }\end{array}$ & $\begin{array}{l}0.0435 \\
(\mathrm{PFU})\end{array}$ & 5 & 0 & 5 \\
\hline & & & & 0.435 & 5 & 1 & 4 \\
\hline & & & & 4.35 & 5 & 5 & 0 \\
\hline
\end{tabular}




\begin{tabular}{|c|c|c|c|c|c|c|c|}
\hline & & & & 43.5 & 5 & 5 & 0 \\
\hline & & & & 435 & 5 & 5 & 0 \\
\hline & & & & 4350 & 5 & 5 & 0 \\
\hline & & & & 43500 & 5 & 5 & 0 \\
\hline \multirow[t]{6}{*}{$\begin{array}{l}\text { R. typhi } \\
\text { (Ethiopian) }\end{array}$} & [8] & i.d. & $\begin{array}{c}\text { Newborn rat } \\
\text { (sero-conversion) }\end{array}$ & $\begin{array}{l}0.0435 \\
\text { (PFU) }\end{array}$ & 8 & 0 & 8 \\
\hline & & & & 0.435 & 8 & 2 & 6 \\
\hline & & & & 4.35 & 8 & 8 & 0 \\
\hline & & & & 43.5 & 8 & 8 & 0 \\
\hline & & & & 435 & 8 & 8 & 0 \\
\hline & & & & 4350 & 8 & 8 & 0 \\
\hline \multirow[t]{5}{*}{$\begin{array}{l}\text { R. typhi } \\
\text { (Ethiopian) }\end{array}$} & [9] & Oral & $\begin{array}{c}\text { Young rat } \\
3 \text { day old } \\
\text { (sero-conversion) }\end{array}$ & $10(\mathrm{PFU})$ & 3 & 1 & 2 \\
\hline & & & & 100 & 6 & 4 & 2 \\
\hline & & & & 1000 & 3 & 3 & 0 \\
\hline & & & & 10000 & 3 & 2 & 1 \\
\hline & & & & 100000 & 5 & 5 & 0 \\
\hline \multirow[t]{5}{*}{$\begin{array}{l}\text { R. typhi } \\
\text { (Ethiopian) }\end{array}$} & [9] & Oral & $\begin{array}{c}\text { Young rat } \\
7 \text { day old } \\
\text { (sero-conversion) }\end{array}$ & $10(\mathrm{PFU})$ & 3 & 1 & 2 \\
\hline & & & & 100 & 3 & 2 & 1 \\
\hline & & & & 1000 & 2 & 2 & 0 \\
\hline & & & & 10000 & 3 & 2 & 1 \\
\hline & & & & 100000 & 3 & 3 & 0 \\
\hline \multirow[t]{5}{*}{$\begin{array}{l}\text { R. typhi } \\
\text { (Ethiopian) }\end{array}$} & [9] & Oral & $\begin{array}{c}\text { Young rat } \\
30 \text { day old } \\
\text { (sero-conversion) }\end{array}$ & 10(PFU) & 3 & 0 & 3 \\
\hline & & & & 100 & 6 & 1 & 5 \\
\hline & & & & 1000 & 3 & 2 & 1 \\
\hline & & & & 10000 & 3 & 2 & 1 \\
\hline & & & & 100000 & 3 & 2 & 1 \\
\hline
\end{tabular}

post inoculation $(T P I)$. In the Beta-Poisson model, the $N_{50}$ parameter is the dose required to produce a response in $50 \%$ of the exposed subjects. Directly related to the growth kinetics of a single organism, the initial dose to elicit response in $50 \%$ of the population $\left(N_{50}\right)$ is also expected to vary with the time when the response is observed. To model these effects, Huang et al. $[14,15]$ set the parameter $k$ and $N_{50}$ equal to functions of time.

\section{Results}

Dose response model for Rickettsia typhi (Murine Typhus) Dose-response model of adult rat exposed intradermally to R. typhi, seroconversion as end point of response

Aringo-Jaramillo et al. (1984) studied an experimental infection with Rickettsia typhi and antibody response of adult and newborn laboratory rats. The best-fit dose response model for seroconversion in intradermally exposed adult rat was the exponential model. The minimized deviance of the exponential model was 0.88 , which was well within the chi-square value at 7 degrees of freedom (i.e. 14.06). The statistics of the two model fits to the animal are summarized in Table 2 and the best-fit model with confidence interval is shown Figure 1.

Dose-response model of newborn rats exposed subcutaneously to $R$. typhi, seroconversion as the end point of response

The best-fit dose response model demonstrating seroconversion in subcutaneously exposed newborn rats was the exponential model. The difference in deviances of the Beta-Poisson and the exponential model was zero. Statistics of the two model fits to the animal are summarized in Table 3 and the bestfit model with confidence intervals shown is in Figure 2. 
Table 2 Model Fit Comparison for Seroconversion in Intradermally inoculated adult rats

\begin{tabular}{|c|c|c|c|c|c|c|c|c|}
\hline $\begin{array}{c}\text { Data } \\
\text { set }\end{array}$ & $\begin{array}{l}\text { Number of } \\
\text { Doses }\end{array}$ & Model & $\begin{array}{c}\text { Minimized } \\
\text { Deviance }\end{array}$ & $\begin{array}{l}\text { Degrees of } \\
\text { Freedom }\end{array}$ & $\chi_{k}^{\chi_{2, n-}}$ & Parameters & $\begin{array}{c}\text { Difference in } \\
\text { deviances }\end{array}$ & $\begin{array}{c}\chi^{2} \text { Value at } 1 \text { degree of } \\
\text { freedom }\end{array}$ \\
\hline \multirow[t]{3}{*}[8]{} & 8 & Exponential* & 0.88 & 7 & 14.06 & $k=0.756$ & 0 & 3.84 \\
\hline & 8 & $\begin{array}{l}\text { Beta } \\
\text { Poisson }\end{array}$ & 0.88 & 6 & 12.59 & $\begin{array}{c}\alpha= \\
01.16 \mathrm{e} 8\end{array}$ & & \\
\hline & & & & & & $\mathrm{N}_{50}=0.91$ & & \\
\hline
\end{tabular}

*Best fit model

Dose-response model of rats of different age groups inoculated orally to $R$. typhi, seroconversion as end point of response

Aringo-Jaramillo et al. (1988) conducted experimental inoculation of $R$. typhi in young rats of different age groups to study the influence of $R$. typhi in maternal rats has on the offspring. Five different doses were inoculated orally in 3-day, 7-day and 30-day old rats and seroconversion was recorded as the end point of response.

Dose-response model of young rat (3-days old) exposed orally to $R$. typhi, seroconversion as the end point of response

The best fit dose response model for seroconversion in orally exposed young rats (3 day old) was the Beta-Poisson model. The minimized deviance of the exponential model exceeded the chi-square value at 5 degrees of freedom, but that of the Beta-Poisson model was well within the critical chi-square value. Statistics of the two model fits to the animal data are summarized in Table 4 and the best-fit model with confidence intervals is shown in Figure 3.

Dose-response model of young rat (7 day old) exposed orally to R. typhi, seroconversion as the end point of response

The best-fit dose response model for seroconversion in orally exposed young rats (7 days old) was the BetaPoisson model. Statistics of the two model fits to the data are summarized in Table 5 and the best-fit model with confidence intervals is shown in Figure 4.

Dose-response model of young rat (30 days old) exposed orally to $R$. typhi, seroconversion as the end point of response

The best fit dose response model for seroconversion in orally exposed young rats (30 days old) was the BetaPoisson model. Statistics of the two model fits to the animal are summarized in Table 6 and the best fit model with confidence intervals is shown in Figure 5.
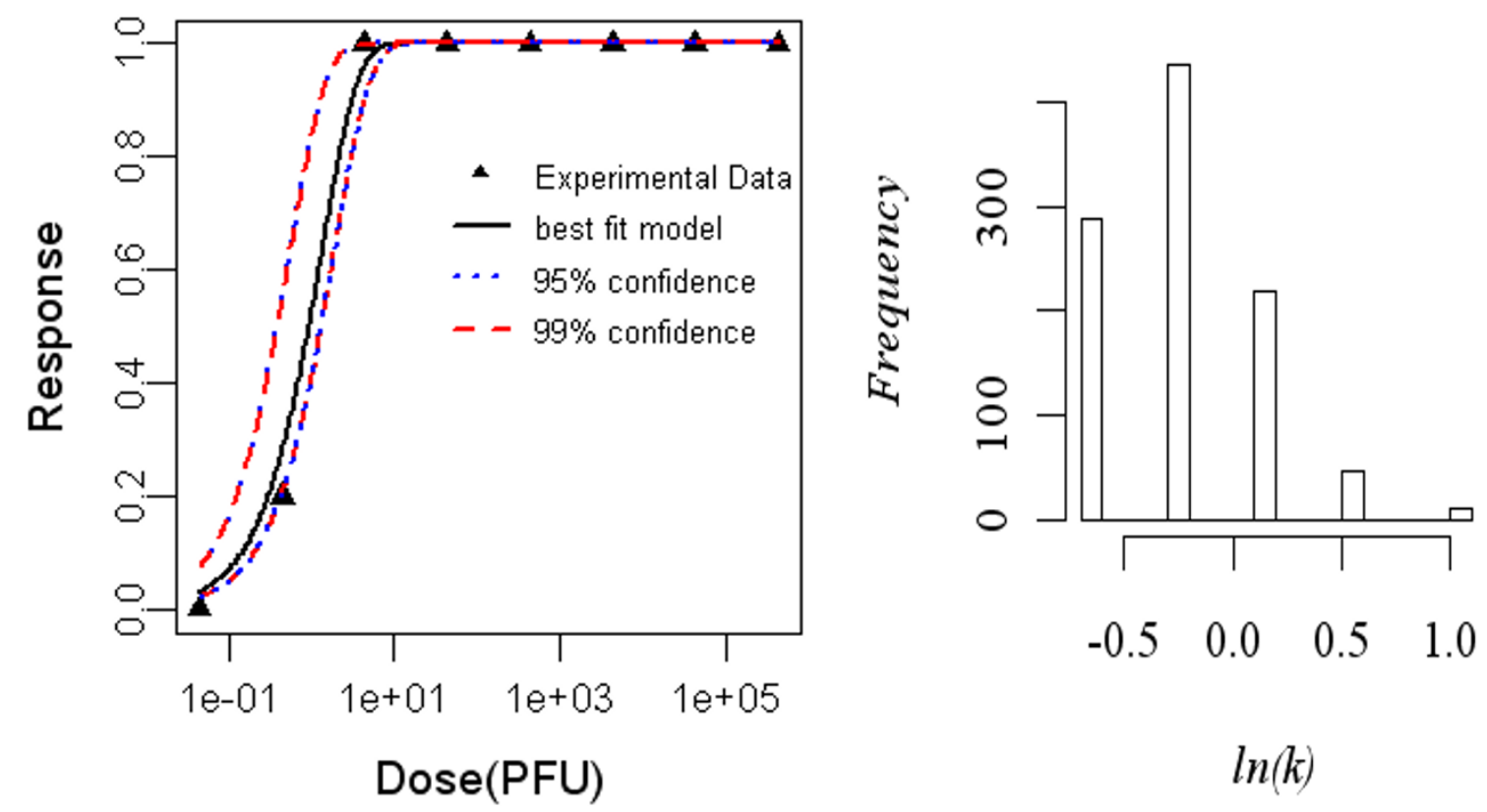

Figure 1 Dose Response Data and Exponential Model Fits for Seroconversion in Intradermally Exposed Adult rat to R. typhi and Bootstrapped Exponential parameters. 
Table 3 Model Fit Comparison for Seroconversion in Subcutaneously Exposed Newborn rats

\begin{tabular}{|c|c|c|c|c|c|c|c|c|}
\hline $\begin{array}{c}\text { Data } \\
\text { set }\end{array}$ & $\begin{array}{c}\text { Number of } \\
\text { Doses }\end{array}$ & Model & $\begin{array}{c}\text { Minimized } \\
\text { Deviance }\end{array}$ & $\begin{array}{l}\text { Degrees of } \\
\text { Freedom }\end{array}$ & $\begin{array}{c}\chi_{\alpha_{2} n-} \\
k\end{array}$ & Parameters & $\begin{array}{c}\text { Difference in } \\
\text { deviances }\end{array}$ & $\begin{array}{c}\chi^{2} \text { Value at } 1 \text { degree of } \\
\text { freedom }\end{array}$ \\
\hline \multirow[t]{3}{*}{ [8] } & 7 & Exponential* & 1.12 & 6 & 12.59 & $k=0.831$ & 0 & 3.84 \\
\hline & 7 & $\begin{array}{l}\text { Beta } \\
\text { Poisson }\end{array}$ & 1.12 & 5 & 11.07 & $\alpha=4.2 \mathrm{e} 7$ & & \\
\hline & & & & & & $\mathrm{N}_{50}=0.83$ & & \\
\hline
\end{tabular}

*Best fit model

Dose-response model with post time inoculation analysis of BALB/c mice exposed subcutaneously to R. typhi, seroconversion as the end point of response

Crist et al. (1984) experimented with R. typhi (R. mooseri) infection in normal and immune mice to study the immune mechanism. Seroconversion after 12, 15, 21, and 28 days of inoculation was best fit to the Beta-Poisson models. Seroconversion after 9 days had only two responses and day zero to day 6 had no response at all. In all models, the minimized deviances were well within the chi-square distribution value at five degrees of freedom. Statistics of the two model fits to the animal test data are summarized in Table 7 and the best fit model with confidence intervals is shown in Figures 6, 7, 8 and 9.

Time-dose-response model for Murine Typhus in BALB/C mice

Huang et al. (Huang, Bartrand et al. 2009; Huang and Haas 2009) proposed a class of time-dose-response models by incorporating the time post inoculation into the classical dose-response models for microbial infection. The parameter $k$ in the exponential doseresponse model and the parameter $N_{50}$ in the Beta-Poisson model were set equal to functions of time, which presumably model the in vivo bacterial kinetics for a single microorganism.

The proposed exponential and Beta-Poisson timedose-response models from these prior studies can be given as:

The exponential and Beta-Poisson model with exponential-reciprocal time dependency-

$$
P(d, T P I)=1-e^{-e^{\left(k_{0} / T P I+k_{1}\right)}} d
$$

where the parameter dependency is given by:

$$
\begin{gathered}
P(d, T P I)=1-\left[1+\frac{d}{e^{\left(j_{0} / T P I+j_{1}\right)}} \times\left(2 \frac{1}{\alpha}-1\right)\right]^{-\alpha} \\
P(d, T P I)=1-\left[1+\frac{d}{e^{\left(j_{0} / T P I+j_{1}\right)}} \times(2 \bar{\alpha}-1)\right]^{-\alpha}
\end{gathered}
$$
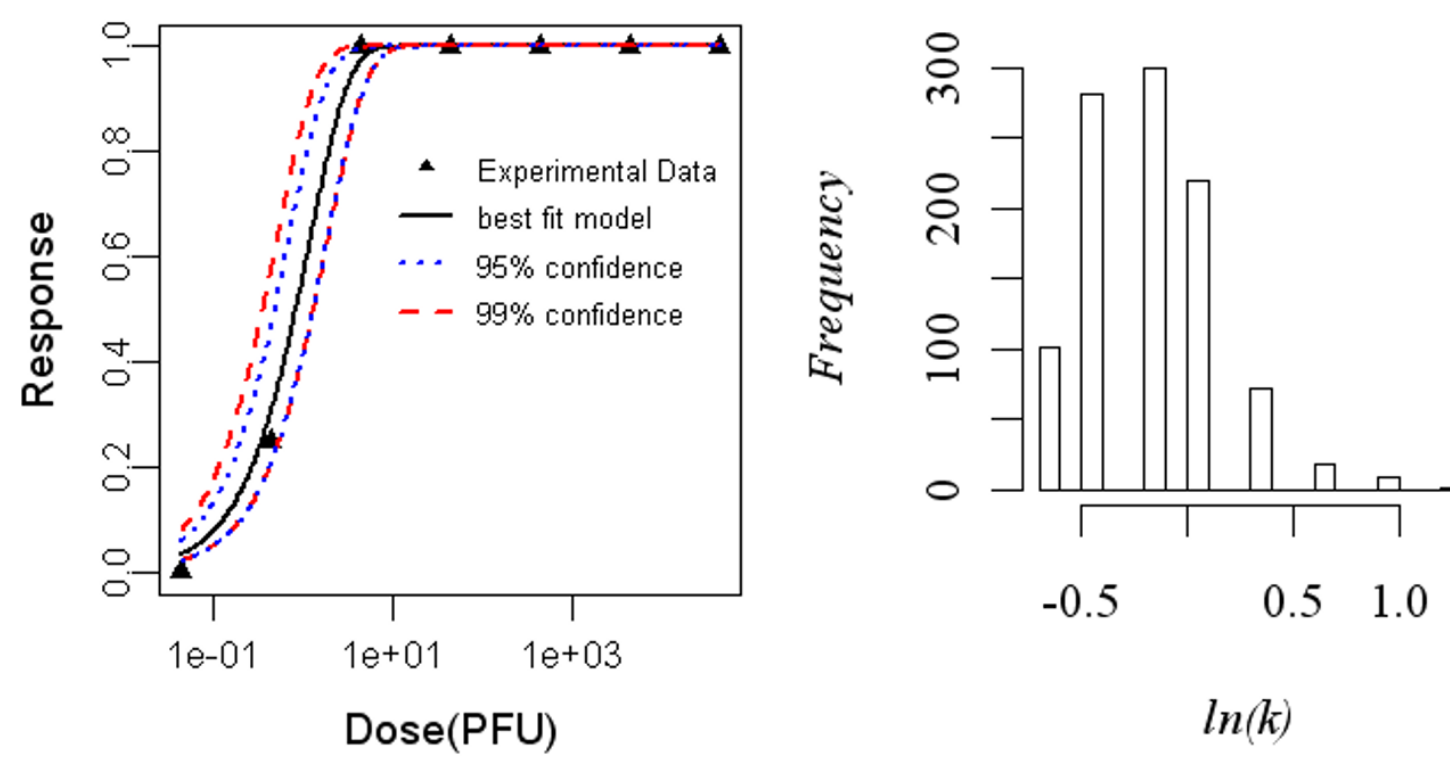

Figure 2 Dose Response Data and Exponential Model Fits for Seroconversion in Subcutaneously Exposed Newborn rat to R. typhi and Bootstrapped Exponential parameters. 
Table 4 Model Fit Comparison for Seroconversion in Oral Exposed Young rat (3 days old)

\begin{tabular}{|c|c|c|c|c|c|c|c|c|}
\hline $\begin{array}{c}\text { Data } \\
\text { set }\end{array}$ & $\begin{array}{c}\text { Number of } \\
\text { Doses }\end{array}$ & Model & $\begin{array}{c}\text { Minimized } \\
\text { Deviance }\end{array}$ & $\begin{array}{l}\text { Degrees of } \\
\text { Freedom }\end{array}$ & $\begin{array}{c}\chi_{\alpha, n-} \\
k\end{array}$ & Parameters & $\begin{array}{c}\text { Difference in } \\
\text { deviances }\end{array}$ & $\begin{array}{c}\chi^{2} \text { Value at } 1 \text { degree of } \\
\text { freedom }\end{array}$ \\
\hline \multirow[t]{3}{*}[9]{} & 5 & Exponential & 34.63 & 4 & 11.07 & $k=0.0006$ & 31.60 & 3.84 \\
\hline & 5 & $\begin{array}{c}\text { Beta } \\
\text { Poisson* }\end{array}$ & 3.023 & 3 & 9.48 & $\alpha=0.286$ & & \\
\hline & & & & & & $\mathrm{N}_{50}=25.7$ & & \\
\hline
\end{tabular}

*Best fit model

where parameter dependency is given by $g(T P I)=e^{\left(j_{0} / T P I+j_{1}\right)}$ The exponential and Beta-Poisson models with power time dependency-

$$
P(d, T P I)=1-e^{\left.-e^{\left(k_{0} /(T P)^{k} k_{2}+k_{1}\right.}\right)} d
$$

where parameter dependency is given by $P(d, T P I)=1-\left[1+\frac{d}{e^{\left(j_{0} /(T P P) j^{\left.j_{2}+j_{1}\right)}\right.}} \times\left(2 \frac{1}{\alpha}-1\right)\right]^{-\alpha}$

$$
P(d, T P I)=1-\left[1+\frac{d}{e^{\left(j_{0} /(T P P) j_{2}+j_{1}\right)}} \times\left(2 \frac{1}{\alpha}-1\right)\right]^{-\alpha}
$$

where parameter dependency is given by $g(T P I)=e^{\left(j_{0} /(T P I)^{j_{2}}+j_{1}\right)}$

The models with candidate time dependencies [13] were fit to the data of the time-dependent antibody response of mice after subcutaneous inoculation of increasing doses of live $R$. typhi to study the time and dose dependence of the antibody response. The
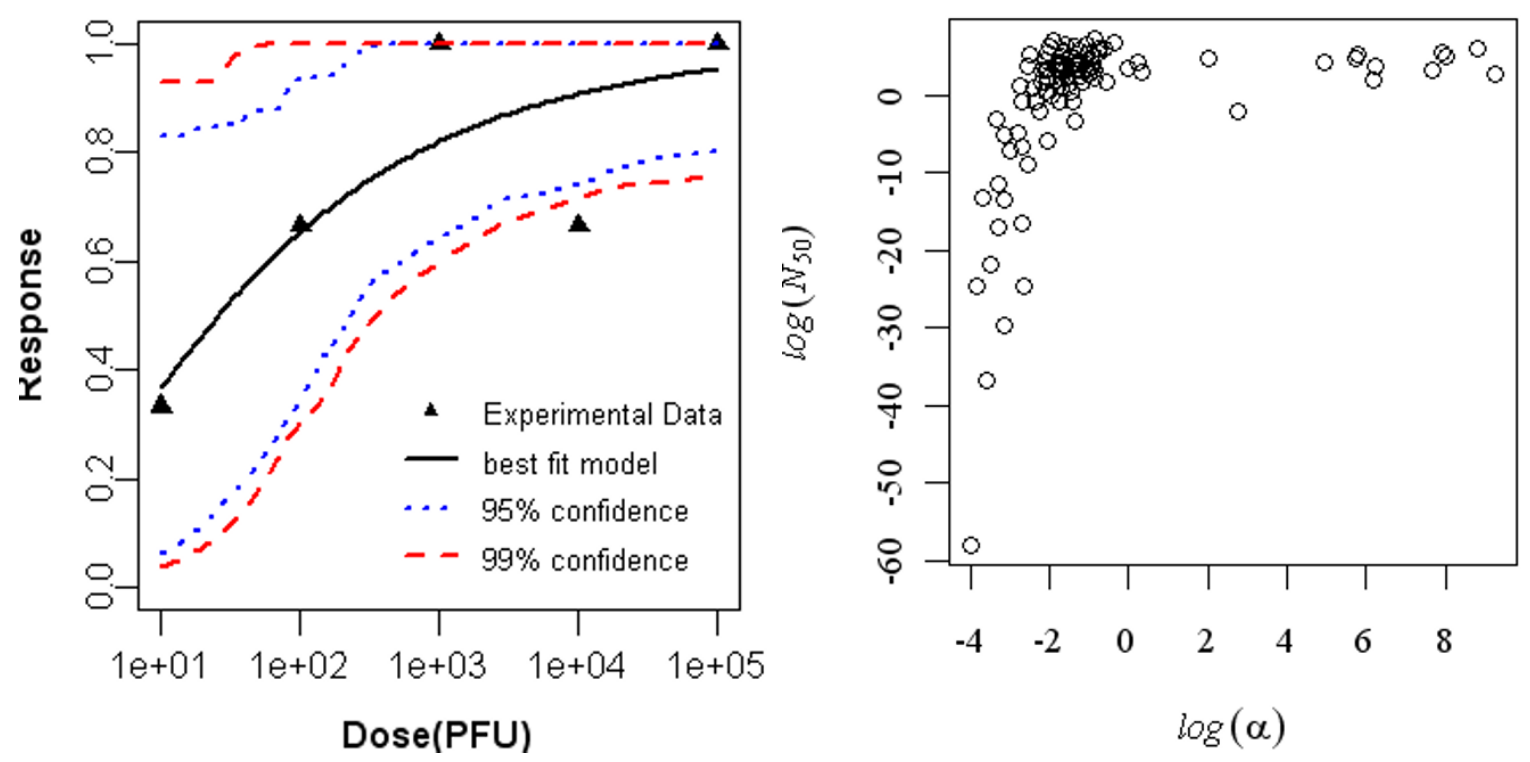

Figure 3 Dose Response Data and Beta-Poisson Model Fits for Seroconversion in Oral Exposed Young rat ( 3 day old) to R. typhi and Bootstrapped Beta-Poisson Parameters.

\begin{tabular}{|c|c|c|c|c|c|c|c|c|}
\hline $\begin{array}{l}\text { Data } \\
\text { set }\end{array}$ & $\begin{array}{l}\text { Number of } \\
\text { Doses }\end{array}$ & Model & $\begin{array}{l}\text { Minimized } \\
\text { Deviance }\end{array}$ & $\begin{array}{l}\text { Degrees of } \\
\text { Freedom }\end{array}$ & $\chi_{\alpha_{2, n-}}$ & Parameters & $\begin{array}{c}\text { Difference in } \\
\text { deviances }\end{array}$ & $\begin{array}{c}\chi^{2} \text { Value at } 1 \text { degree of } \\
\text { freedom }\end{array}$ \\
\hline \multirow[t]{3}{*}{ [9] } & 5 & Exponential & 66.172 & 4 & 11.07 & $k=0.0149$ & 63.83 & 3.84 \\
\hline & 5 & $\begin{array}{c}\text { Beta } \\
\text { Poisson* }\end{array}$ & 2.34 & 3 & 9.48 & $\alpha=0.241$ & & \\
\hline & & & & & & $N_{50}=28.92$ & & \\
\hline
\end{tabular}

Table 5 Model Fit Comparison for Seroconversion in Oral Exposed Young rat (7 day old) 


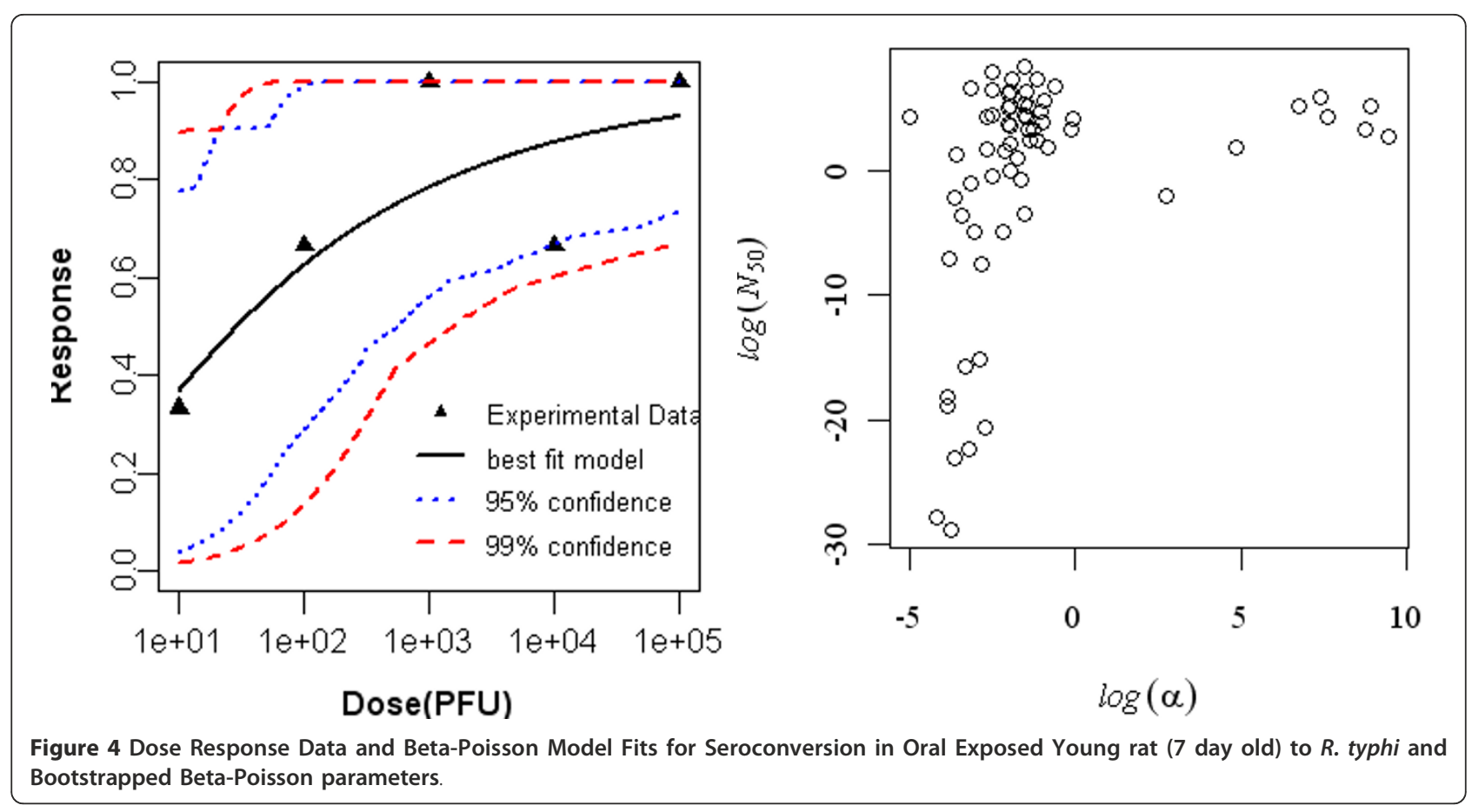

Table 6 Model Fit Comparison for Seroconversion in Oral Exposed Young rat (30 day old)

\begin{tabular}{|c|c|c|c|c|c|c|c|c|}
\hline $\begin{array}{l}\text { Data } \\
\text { set }\end{array}$ & $\begin{array}{l}\text { Number of } \\
\text { Doses }\end{array}$ & Model & $\begin{array}{l}\text { Minimized } \\
\text { Deviance }\end{array}$ & $\begin{array}{l}\text { Degrees of } \\
\text { Freedom }\end{array}$ & 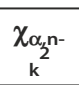 & Parameters & $\begin{array}{l}\text { Difference in } \\
\text { deviances }\end{array}$ & $\begin{array}{c}\chi^{2} \text { Value at } 1 \text { degree of } \\
\text { freedom }\end{array}$ \\
\hline \multirow[t]{3}{*}{ [9] } & 5 & Exponential & 20.55 & 4 & 11.07 & $K=4.2 \mathrm{e}-5$ & 19.55 & 3.84 \\
\hline & 5 & $\begin{array}{c}\text { Beta } \\
\text { Poisson* }\end{array}$ & 1.0 & 3 & 9.48 & $\alpha=0.20$ & & \\
\hline & & & & & & $\mathrm{N}_{50}=16.17$ & & \\
\hline
\end{tabular}
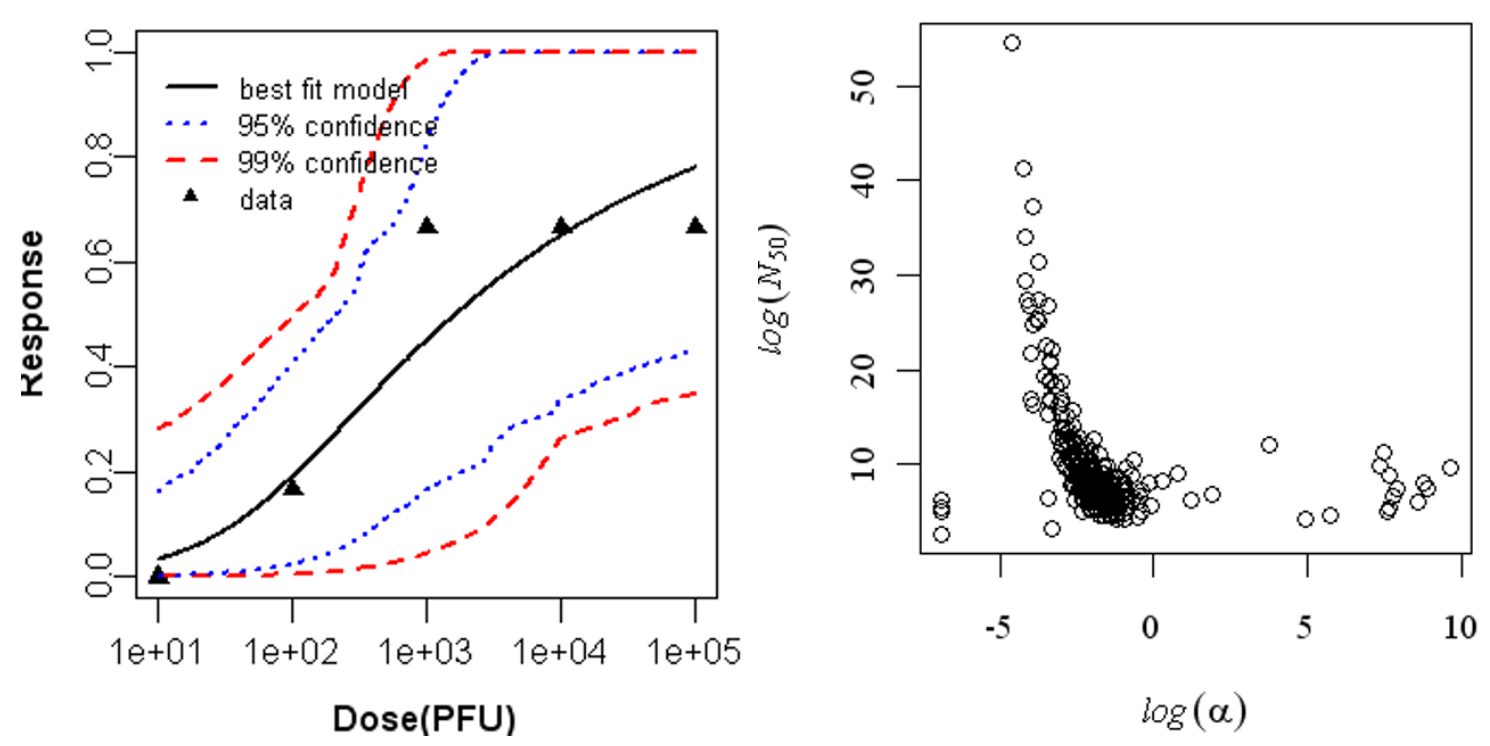

Figure 5 Dose Response Data and Beta-Poisson Model Fits for Seroconversion in Oral Exposed Young rat (30 day old) to R. typhi and Bootstrapped Beta-Poisson parameters. 
Table 7 Best fit model for seroconversion on different days after inoculation in subcutaneously exposed BALB/c mice

\begin{tabular}{|c|c|c|c|c|c|c|}
\hline Data & Number of Doses & Model & Minimized Deviance & Degrees of Freedom & $\chi_{\alpha, n-k}^{2}$ & Parameters \\
\hline \multirow[t]{2}{*}{ Seroconversion after day 12} & 7 & Beta Poisson* & 4.19 & 5 & 11.07 & $\alpha=0.79$ \\
\hline & & & & & & $\mathrm{N}_{50}=94.80$ \\
\hline \multirow[t]{2}{*}{ Seroconversion after day 15} & 7 & Beta Poisson* & 1.40 & 5 & 11.07 & $\alpha=0.57$ \\
\hline & & & & & & $\mathrm{N}_{50}=10.46$ \\
\hline \multirow[t]{2}{*}{ Seroconversion after day 21} & 7 & Beta Poisson* & 2.77 & 5 & 11.07 & $\alpha=0.60$ \\
\hline & & & & & & $N_{50}=1.67$ \\
\hline \multirow[t]{2}{*}{ Seroconversion after day 28} & 7 & Beta Poisson* & 1.59 & 5 & 11.07 & $\alpha=0.72$ \\
\hline & & & & & & $\mathrm{N}_{50}=0.28$ \\
\hline
\end{tabular}

*Best fit model
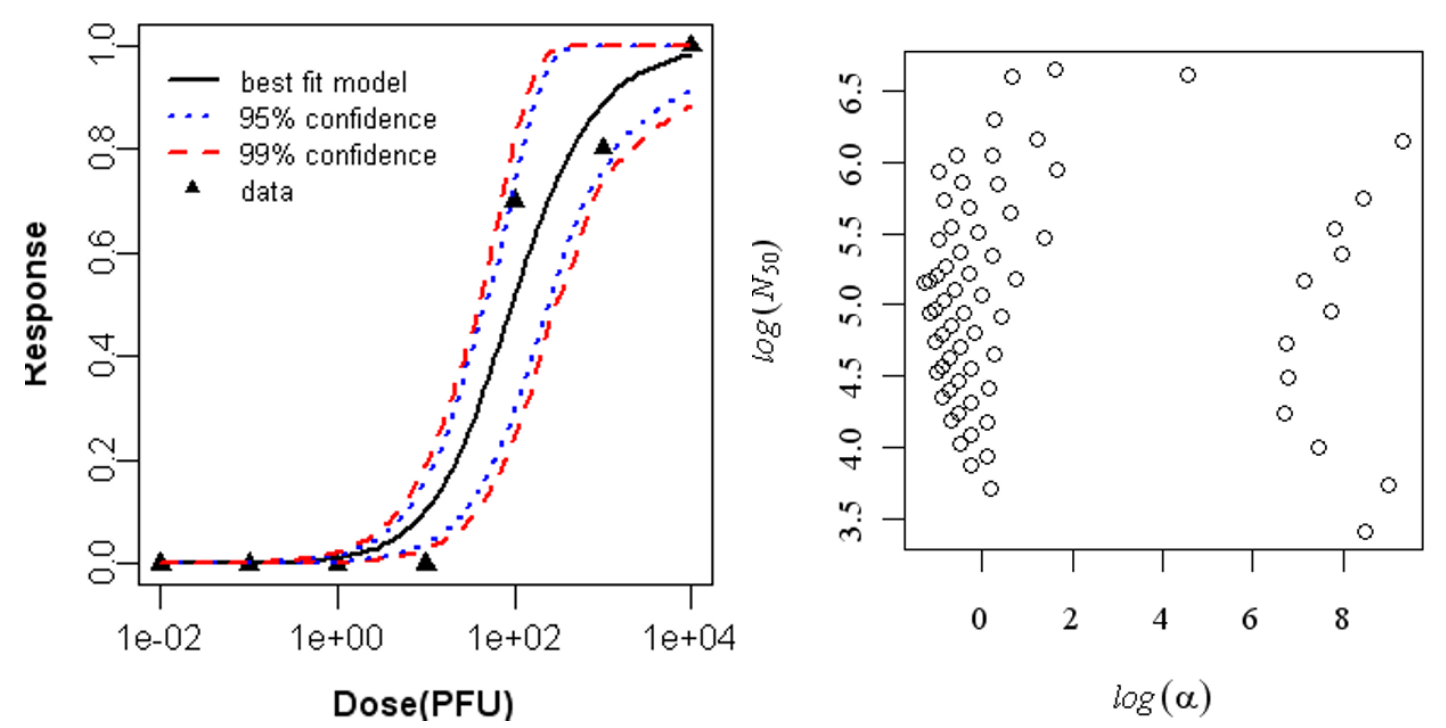

Figure 6 Dose Response Data and Beta-Poisson Model Fits for Seroconversion (12 days after inoculation) in Subcutaneously Exposed $\mathrm{BALB} / \mathrm{c}$ mice to $R$. typhi and Bootstrapped Beta-Poisson parameters.
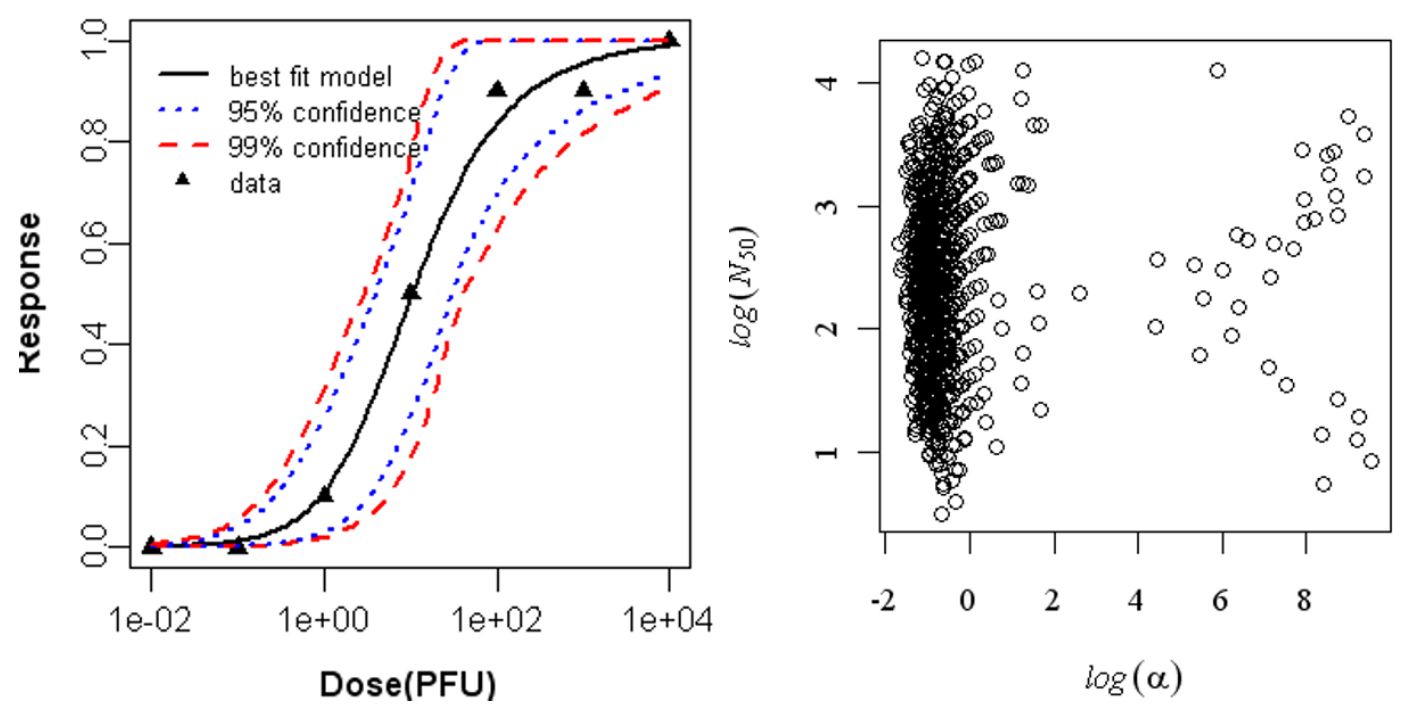

Figure 7 Dose Response Data and Beta-Poisson Model Fits for Seroconversion (15 days after inoculation) in Subcutaneously Exposed $\mathrm{BALB} / \mathrm{c}$ mice to $R$. typhi and Bootstrapped Beta-Poisson parameters. 

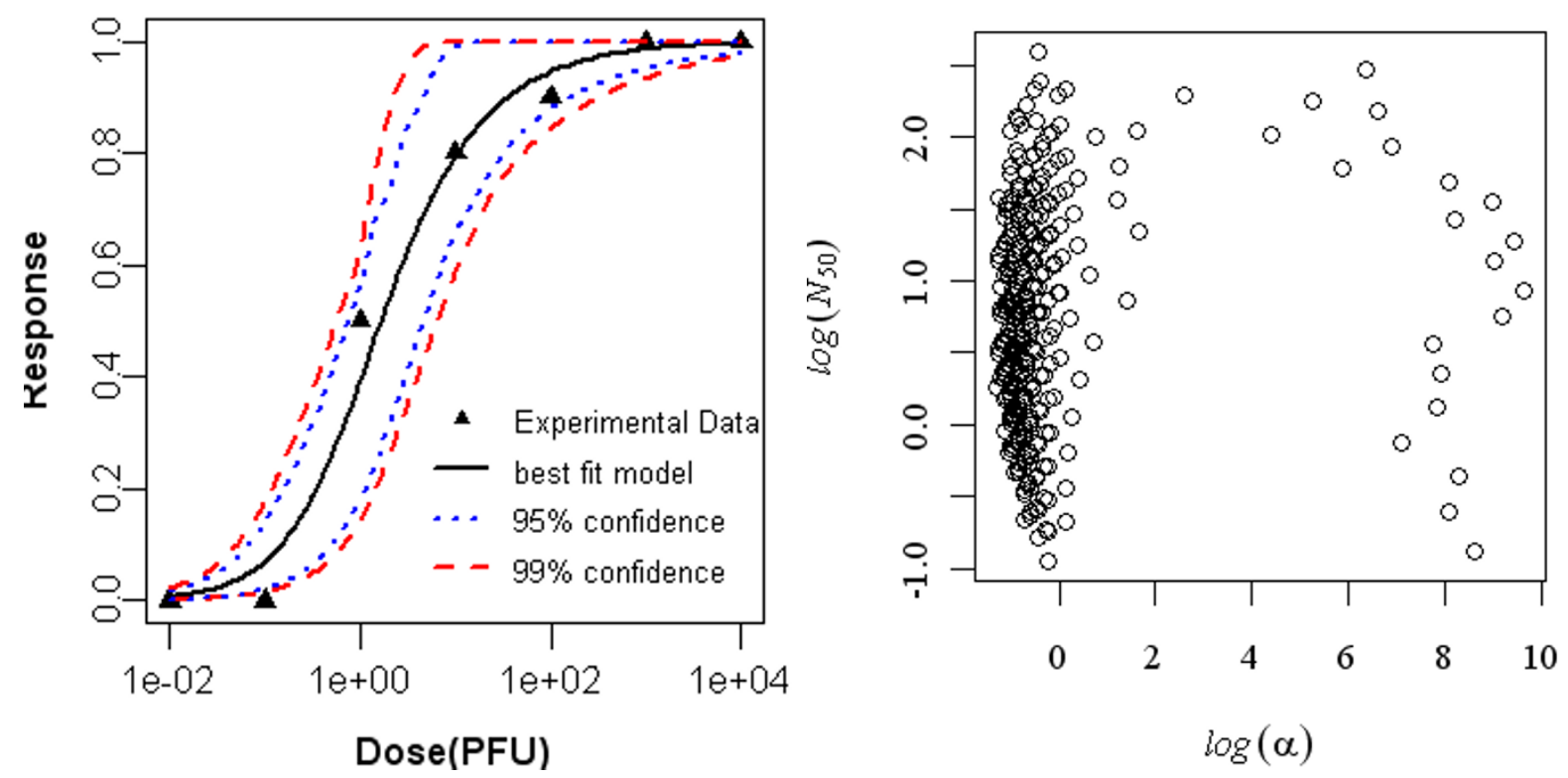

Figure 8 Dose Response Data and Beta-Poisson Model Fits for Seroconversion (21 days after inoculation) in Subcutaneously Exposed BALB/c mice to R. typhi and Bootstrapped Beta-Poisson parameters.

minimum deviances generated by equation (3), (4), (5) and (6) were $109.24,26.98,104.66$ and 26.47 respectively. The two-parameter modified Beta-Poisson model based on equation (4) provided the best (and statistically acceptable) fit to the data. The best-fit model was then plotted to compare visually with the antibody response in Figure 10. It can be seen that the model is closely aligned with the data.

\section{Pooling analysis}

Pooling analysis was performed to ascertain whether different data sets could be described by a single doseresponse relationship. Different combinations of species, strains, routes of infection and hosts were pooled together and a likelihood ratio test was used to determine whether the data could be pooled or not.
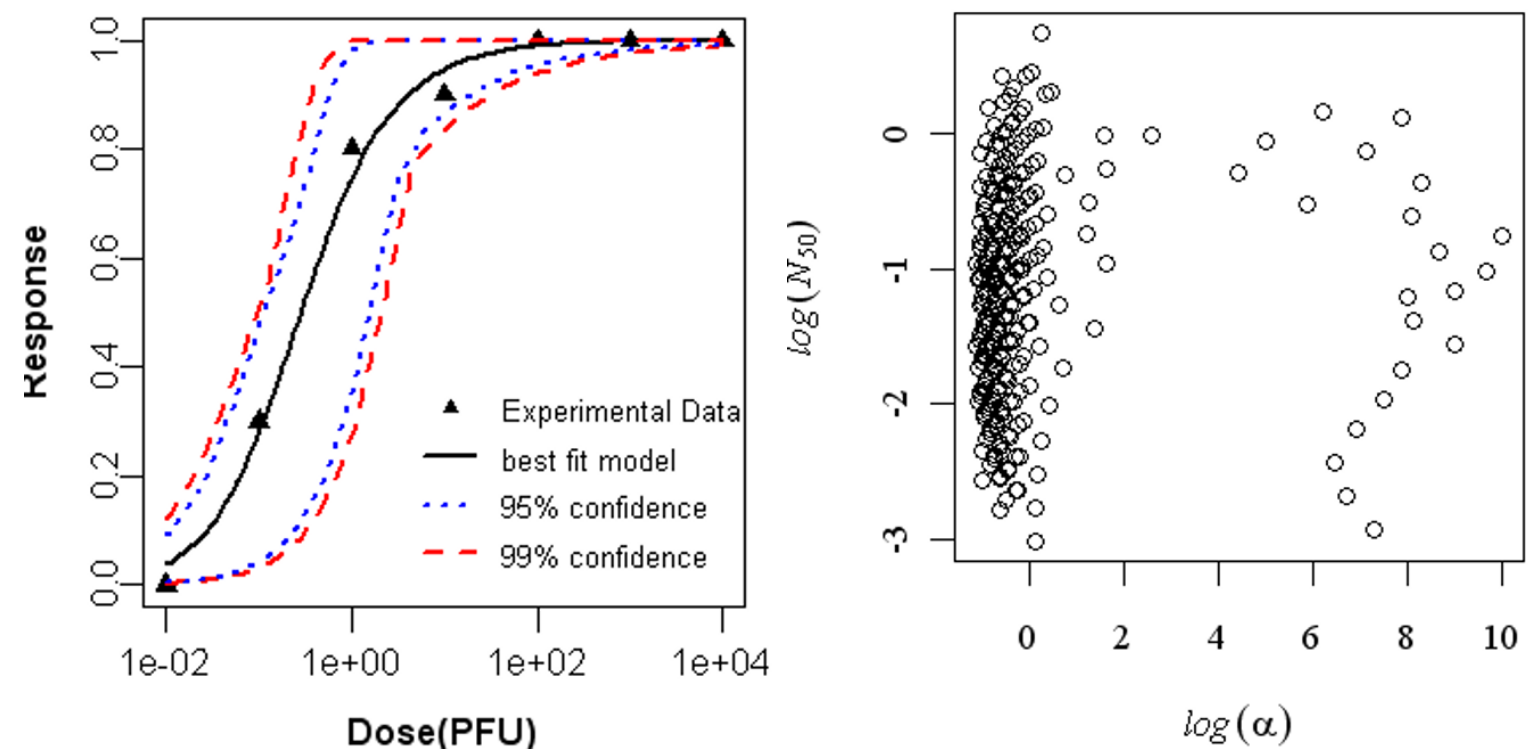

Figure 9 Dose Response Data and Beta-Poisson Model Fits for Seroconversion (28 days after inoculation) in Subcutaneously Exposed $\mathrm{BALB} / \mathrm{c}$ mice to $R$. typhi and Bootstrapped Beta-Poisson parameters. 
The intradermally inoculated adult rats and subcutaneously inoculated newborn rats with $R$. typhi (Ethiopian strain) could be pooled. The difference in deviances between the sum of individual best fits and the pooled model's best fit was zero which was less thanthe $\chi^{2}$ 0.05,1 value (3.841). The summary and statistics of the pooling analysis are shown in Table 8 and the best fit model is shown in Figure 11.

Similarly, young rats of different age groups were orally exposed to graded doses of $R$. typhi orally. All the data could be pooled irrespective of the age of the animals. The value of the difference in deviances between sum of individual best fits and pooled best fit was 0.01 which was less than $\chi^{2} \quad 0.05,1$ value (3.841). Statistics of the pooled data are summarized in Table 9 and best fit model of the pooled data is shown in Figure 12.

\section{Discussion}

Aringo-Jaramillo et al. (1984) studied the antibody response of adult and newborn laboratory rats exposing them intradermally and subcutaneously with $R$. typhi. Both newborn (3 day old) and adult rats were highly susceptible to $R$. typhi inoculated either subcutaneously or intradermally. The $\mathrm{ID}_{50}$ for adult rat was $0.91 \mathrm{PFU}$ and for newborn rat was 0.88 PFU. Both routes of infection are considered natural mode of infection analogues to a flea bite[16]. The exponential model provided the best fit in both cases, indicating that the responses were homogenous in the population, and the routes of infection were interchangeable statistically. Moreover, the data could be pooled and as shown in Figure 11, the best fit lines of each of the individual models and the pooled model overlapped one another indicating that responses in rats are independent of the age factor and mode of inoculation (intradermal and subcutaneous). The comparative table as shown in Table 10 also shows there are no significant differences in $\mathrm{ID}_{50}, \mathrm{ID}_{10}$ and $\mathrm{ID}_{01}$.

Similarly, Aringo-Jaramillo et al. (1988) studied the influence of maternal $R$. typhi in young rats of different

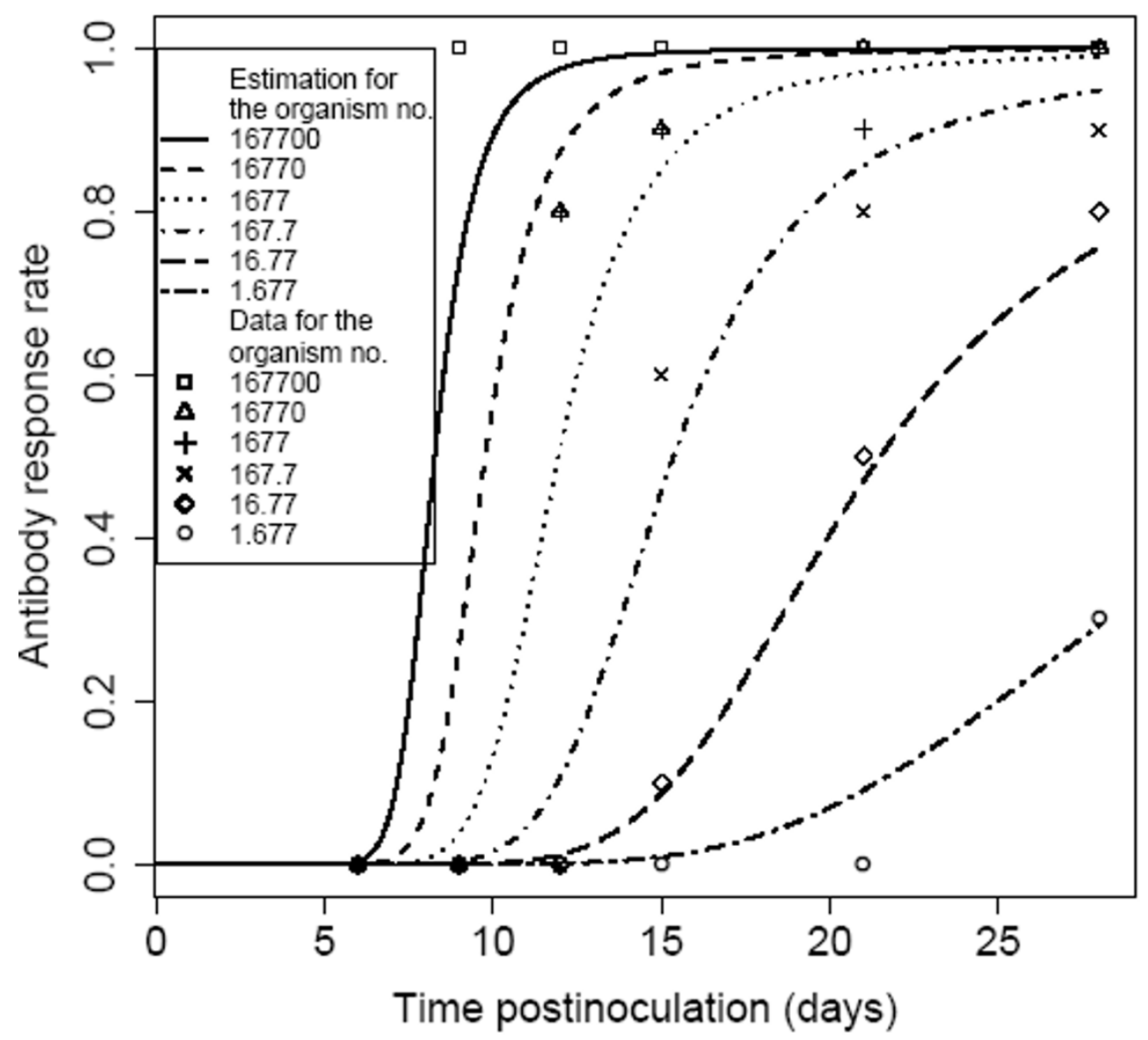

Figure 10 Time-Dependent Model for Antibody Response of BALB/c mice after subcutaneous inoculation of increasing doses of live $R$. mooseri. 
Table 8 Adult rat and Newborn rat Pooled Data

\begin{tabular}{ccccccc}
\hline Data & Number of Doses & Best fit Model & Minimized Deviance & Degrees of Freedom & $\boldsymbol{\chi}_{\boldsymbol{\alpha}, \mathbf{n}-\mathbf{k}}{ }^{\mathbf{2}}$ & Parameters \\
\hline Adult rat exposed intradermally & 8 & Exponential & 0.88 & 7 & 14.06 & $\mathrm{~K}=0.756$ \\
\hline Newborn rat exposed subcutaneously & 7 & Exponential & 1.12 & 6 & 12.59 & $\mathrm{~K}=0.831$ \\
\hline Pooled data & 15 & Exponential & 2.0 & 14 & 23.68 & $\mathrm{~K}=0.801$ \\
\hline
\end{tabular}

age groups inoculating $R$. typhi orally. All data for every age of rat (3 day-old, 7 day-old and 30 day-old) could be pooled and represented by a best fit Beta-Poisson model. Scattered points at right of the graphs (Figure 6, 7 and 8 ) are high alpha values and those points tend to fit exponential model while majority $99.9 \%$ were at dense cluster. The result indicates that the rats inoculated orally show homogeneity in response and a single dose-response relationship could describe all the age groups. There are no significant differences in $\mathrm{ID}_{50} \mathrm{~S}$ of individual age groups but the median infective value is significantly higher than rats inoculated intradermally or subcutaneously. The reason behind the higher $\mathrm{ID}_{50}$ may be the route of inoculation. The number of pathogens that reach endothelial cells via the oral route might significantly be less than the initial inoculation.

Crist et al. (1984) recorded post time inoculation responses while inoculating $R$. typhi (R. mooseri) to $\mathrm{BALB} / \mathrm{c}$ mice. In days 0-6, there was no response. There was only one response at the highest dose on day 9 . From day 12 to 28 , there were systemic responses to corresponding doses. The data of seroconversion of $\mathrm{BALB} / \mathrm{c}$ mice after days 12, 15, 21 and 28 were best fit to a Beta-Poisson model. The post inoculation effect

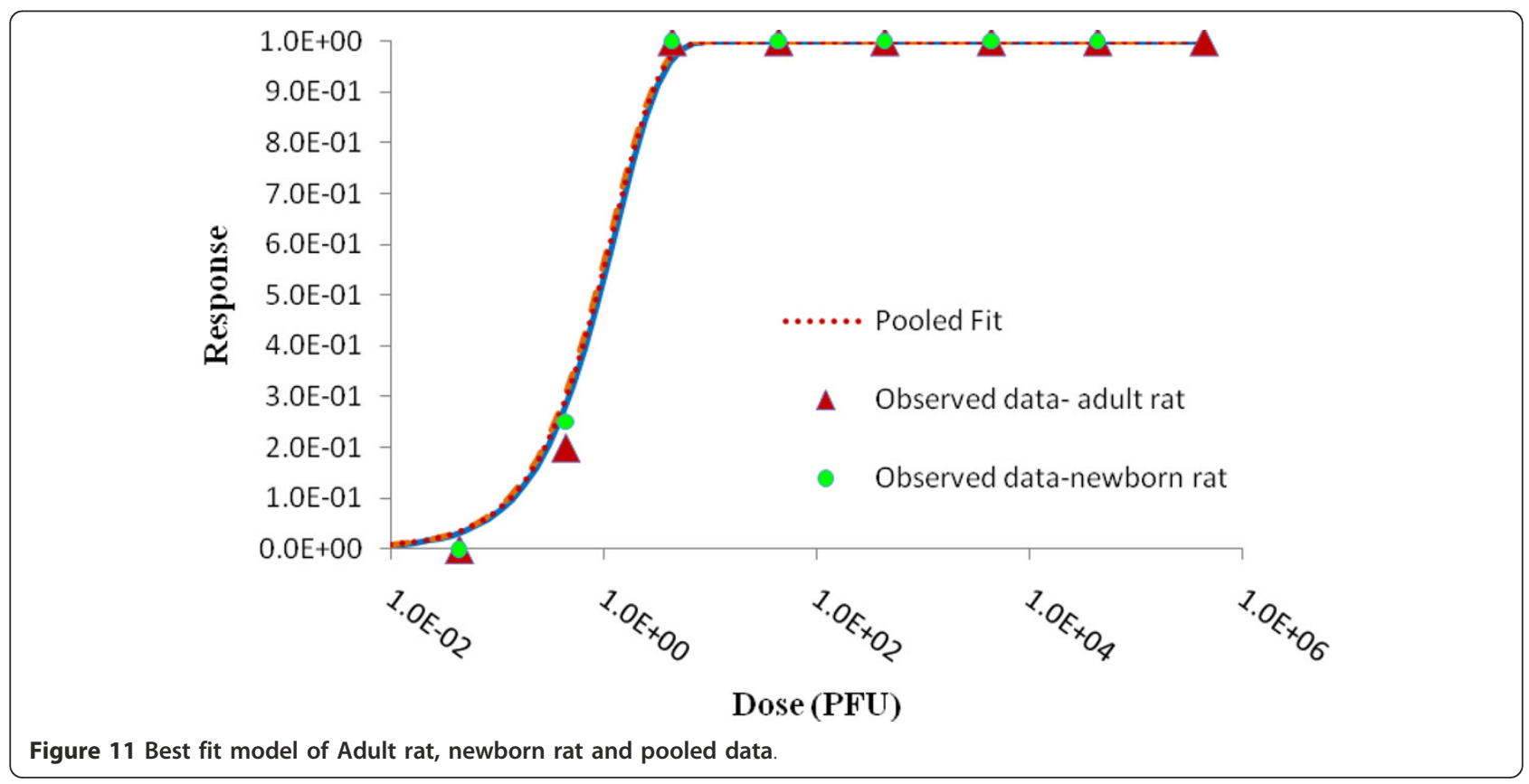

Table 9 Young rat of different ages Pooled Data

\begin{tabular}{|c|c|c|c|c|c|c|}
\hline Data & Number of Doses & Best fit Model & Minimized Deviance & Degrees of Freedom & $\chi_{\alpha, n-k}^{2}$ & Parameters \\
\hline \multirow[t]{2}{*}{ Young rat 3-day old } & 5 & Beta-Poisson & 3.023 & 3 & 7.81 & $\alpha=0.286$ \\
\hline & & & & & & $\mathrm{N}_{50}=25.7$ \\
\hline \multirow[t]{2}{*}{ Young rat 7-day old } & 5 & Beta-Poisson & 2.34 & 3 & 7.81 & $\alpha=0.241$ \\
\hline & & & & & & $\mathrm{N}_{50}=28.92$ \\
\hline \multirow[t]{2}{*}{ Young rat 30-day old } & 5 & Beta-Poisson & 1.0 & 3 & 7.81 & $\alpha=0.20$ \\
\hline & & & & & & $\mathrm{N}_{50}=16.17$ \\
\hline \multirow[t]{2}{*}{ Pooled data } & 15 & Beta-Poisson & 13.53 & 13 & 22.36 & $\alpha=0.213$ \\
\hline & & & & & & $N_{50}=106.14$ \\
\hline
\end{tabular}




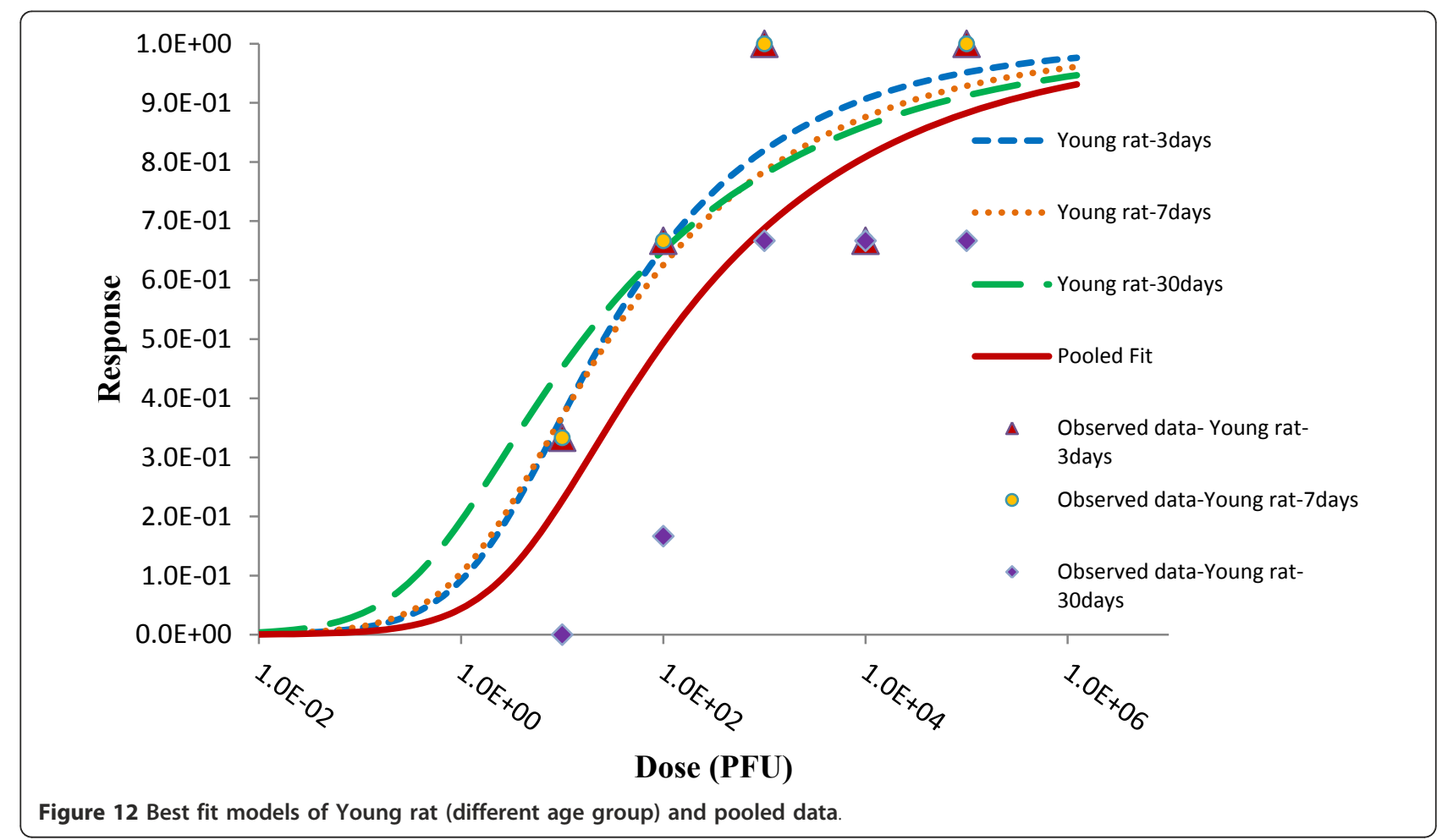

was analyzed with the data set using a time post inoculation model as described in prior work [13,14]. Figure 10 shows the different dose-response curves for different time (days) after inoculation.

\section{Conclusion}

Human murine typhus caused by Rickettsia typhi ( $R$. mooseri) is an infectious disease that requires the fewest number of pathogens to initiate disease. The doseresponse models developed in this study support this effect. Intradermally or subcutaneously inoculated rats (adult and newborn) dose response models suggest that less than 1 PFU (ranging between 0.38 and 1.33 PFU as estimated within the models' $95 \%$ confidence limits) of the pathogen is enough to seroconvert $50 \%$ of the exposed population o average. The BALB/c mouse time post inoculation model also indicates that an average dose of 0.28 PFU (0.75 to 0.11 PFU within a $95 \%$ confidence interval) will cause seroconversion in of $50 \%$ of the exposed population with a mean time to effect of 28 days. The difference in median infectious dose (seroconversion) in adult rat and BALB/c mice is not a significant one and it may be because of the different strains of pathogen used to infect the test subjects. The model suggests that the higher the number of pathogens, the sooner the seroconversion. Pooling analysis of adult and newborn rats shows that there is no significant effect due to different routes of inoculation and can be described by the same dose-response relationship. Similarly, pooling of orally inoculated young rats of different age groups indicates that there is no significant effect of age in serocenversion. However, there is an observed variation in response related to age groups seen in human case studies. According to Al-Awadi et al., the most susceptible age group was the 15-25 years, followed by the 26 to 44 year age group. But there is no definite pattern of variation $[17,18]$. This is also the first study to incorporate time in a dose-response model for murine typhus. The outcome may improve current understanding of in vivo bacterial dynamics, post-

Table 10 Comparative values of ID50, ID10 and ID01

\begin{tabular}{cccccc}
\hline Pathogen & Host & Route & ID $_{\mathbf{0 1}}$ & ID $_{\mathbf{1 0}}$ & $\mathbf{I D}_{\mathbf{5 0}}$ \\
\hline R. mooseri & Newborn rat & sc & 0.012 & 0.12 & 0.83 \\
\cline { 2 - 6 } & Adult rat & id & 0.013 & 0.14 & 0.91 \\
\cline { 2 - 7 } & Pooled data & & 0.012 & 0.13 & 0.86 \\
\hline
\end{tabular}

sc $=$ subcutaneous

id = intradermal 
exposure decision-making or as a component to assist epidemiological investigations.

\section{Acknowledgements}

The advice of Sondra Teske (post-doctoral associate) is gratefully acknowledged. This work was performed as part of the Center for Advancing Microbial Risk Assessment (CAMRA). CAMRA is a US EPA/ Department of Homeland Security Cooperative Center of Excellence funded under USEPA STAR grant R83236201. This work does not express official policy of either USEPA or the Department of Homeland Security.

\section{Authors' contributions}

$\mathrm{CNH}$ was responsible for conception, acquisition of funding and supervision of the group. SBT made substantial contribution to data collection, study design, analysis and interpretation of data and drafting manuscript. YH contributed to "time post inoculation" section of the manuscript and SST contributed in revising manuscript. All the authors read and approved the final manuscript.

\section{Competing interests}

The authors declare that they have no competing interests.

Received: 4 October 2010 Accepted: 30 March 2012

Published: 30 March 2012

\section{References}

1. Azad AF, Traub R: Transmission of Murine Typhus Rickettsiae by Xenopsylla cheopis, with Notes on Experimental Infection and Effects of Temperature. The American Journal of Tropical Medicine and Hygiene 1985, 34:555-563.

2. Azad AF: Epidemiology of Murine Typhus. Annu Rev Entomol 1990, 35:553-570.

3. Houhamdi Fournier PE, Fang R, Raoult D: An experimental model of human body louse infection with Rickettsia typhi. Annal of the New York Academy of Sciences 2003, 990:617-627.

4. Walker DH: Rickettsiae. In Medical Microbiology.. 4 edition. Edited by: Samuel Baron M. Irving, TX: University of Texas Medical Branch at Galveston; 1996:

5. Azad AF, Radulovic S, Higgins JA, Noden BH, Troyer JM: Flea-borne Rickettsioses: ecologic considerations. Emerg Infect Dis 1997. 3:319-327.

6. McLeod MP, Qin X, Karpathy SE, Gioia J, Highlander SK, Fox GE, McNeill TZ, Jiang $H$, Muzny D, Jacob $L S$, et al: Complete genome sequence of Rickettsia typhi and comparison with sequences of other Rickettsiae. J Bacteriol 2004, 186:5842-5855.

7. Fergie JE, Purcell K, Wanat D: Murine typhus in South Texas children. Pediatr Infect Dis J 2000, 19:535-538.

8. Arango-Jaramillo S, Azad AF, Wisseman CL Jr: Experimental infection with Rickettsia mooseri and antibody response of adult and newborn laboratory rats. AmJTrop Med Hyg 1984, 33:1017-1025.

9. Arango-Jaramillo S, Wisseman CL Jr, Azad AF: Newborn rats in the murine typhus enzootic infection cycle: studies on transplacental infection and passively acquired maternal antirickettsial antibodies. AmJTrop Med Hyg 1988, 39:391-397.

10. Crist EA, Wisseman CL, Murphy JR: Characteristics of Rickettsia mooser infection of normal and immune mice. Infect Immun 1984, 43:38-42.

11. Haas CN, Rose JB, Gerba CP: Quantitative Microbial Risk Assessment John Wiley and Sons, Inc (New York); 1999.

12. Teunis PF, Havelaar AH: The beta poisson dose response model is not a single-hit model. Risk Anal 2000, 20:513-520.

13. Huang $Y$, Haas CN: Time-dose-response models for microbial risk assessment. Risk Anal 2009, 29:648-661.

14. Huang $Y$, Bartrand TA, Haas CN, Weir MH: Incorporating time postinoculation into a dose-response model of Yersinia pestis in mice. $J$ Appl Microbiol 2009, 107:727-735.

15. Huang Y, Haas CN: Time-dose-response models for microbial risk assessment. Risk Anal 2009, 29:648-661.

16. Walker DH: Rocky Mountain spotted fever: a disease in need of microbiological concern. Clin Microbiol Rev 1989, 2:227-240.
17. Brown AE, Meek SR, Maneechai N, Lewis GE: Murine typhus among Khmers living at an evacuation site on the Thai-Kampuchean border. AmJTrop Med Hyg 1988, 38:168-171.

18. Al-Awadi AR, Ai-Kazemi N, Ezzat G, Saah AL, Shepard C, Zaghloul T, Gherdian B: Murine typhus in Kuwait in 1978. Bull World Health Organ 1982, 60:283-289.

\section{Pre-publication history}

The pre-publication history for this paper can be accessed here: http://www.biomedcentral.com/1471-2334/12/77/prepub

doi:10.1186/1471-2334-12-77

Cite this article as: Tamrakar et al: Dose-response model of murine typhus (Rickettsia typhi): time post inoculation and host age dependency analysis. BMC Infectious Diseases 2012 12:77.

\section{Submit your next manuscript to BioMed Central and take full advantage of:}

- Convenient online submission

- Thorough peer review

- No space constraints or color figure charges

- Immediate publication on acceptance

- Inclusion in PubMed, CAS, Scopus and Google Scholar

- Research which is freely available for redistribution

Submit your manuscript at www.biomedcentral.com/submit 